\title{
Politics and the paradox of power in Femi Osofisan's Many Colours Make the Thunder-King
}

\author{
Adebola ADEMESO \\ Department of Theatre Arts and Music, Lagos State University Ojo, Lagos, Nigeria.
}

Received 24 December, 2013; Accepted 21 August, 2014

\begin{abstract}
The dominant trend in the world of politics today is a radical and spontaneous move towards a state of terrorism in a bid to show a big line between the strong and the weak nations; between the powerful and the powerless individuals in a postcolonial state, and the paradox of this action is that it gradually leads to self destruction, and a rape on human dignity and pride which the perpetrators of this act seek to redeem and protect. In this study, however, Femi Osofisan's Many Colours make the Thunder-King is examined within the confines of his advocacy against the expanding waves of terrorism in modern society, and how, perhaps, this could be curtailed through stage craft.
\end{abstract}

Key words: Terrorism, drama, power, politics, inordinate ambition.

\section{INTRODUCTION}

Terrorism is the deliberate creation and exploitation of fear for bringing about political change. All terrorist acts involve violence or equally important- the threat of violence...

Terrorists attempt not only to sow panic but also to undermine confidence in the government and political leadership of their target country. Terrorism is therefore designed to have psychological effects that reach far beyond its impact on the immediate victims or object of an attack. Terrorists mean to frighten and thereby intimidate a wider audience, such as a rival ethnic or religious group, an entire country and its political leadership, or the international community as a whole. If terrorism is truly a deliberate creation of the perpetrators with the aim of exploiting the victims in the most dehumanizing ways, then the word politics has drifted away from the phenomenon of human relations and diplomacy; it has assumed the status of a violent destruction of humanity, especially in the areas of policy formulation and implementation. It must also be noted that the causes of this heinous act are not restricted to politics but could also be traced to historical, social, psychological, economic, religious and cultural background or the ambitions of the perpetrators or a combination of these factors. However, terrorism and inordinate ambition are vital tools in the modern world politics, and a paradox of power.

\section{Terrorism and inordinate ambition}

The most fundamental of all the causes of terrorism is the inordinate ambition of the actors of terrorism and their disregard for their victims. The tendency to capture,

E-mail: bolames6@yahoo.com.Tel: 08033270469,018547639.

Author agree that this article remain pemanently open access under the tems of the Creative Commons Attribution Lic ense 4.0 Intemational Lic ense 
either in part or in full, the environment by the terror is the driving force, although the terrorist may not see his action as an act of terrorism because his ambition may have beclouded his sense of rational judgment. For instance, a large percentage of Iraqi citizens still believe in the cause pursued by Saddam Hussein despite the fact that it was regarded as an act of terror by the international community. The desire to want to achieve a great feat in life, and be successful, irrespective of how one achieves that goal, becomes ambition, and this ambition becomes excessive, beyond reasonable limits in nature, when it is an inordinate one. States (or nations) and certain individuals in history have been variously labelled thus. For instance,

The U.S. Department of State has designated seven countries as state sponsors of terrorism: Iran, Iraq, Syria, Libya, Cuba, North Korea, and Sudan. In the year 2002, it named Iran as the most active supporter of terrorism for aid to groups such as Hezbollah Hamas, and Palestine Islamic Jihad. Although the former Taliban government of Afghanistan sponsored Al-Qaeda, the radical group was led by Saudi exile, Osama Bin Laden... (Hoffman, 2007:43)

The U.S.A. government has also been classified as a breeder of terrorists because most of the notable terrorist nations and individuals are former allies and students in the United States who have now decided to reason on their own. One of such people is Osama Bin Laden and examples of such nations are Iran and Iraq.

In 1990/1991, the U.S government launched attacks on Iraq over the oil-rich Peninsula of Kuwait which led to what is known in history as the Persian Gulf War, headed by George Herbert Walker Bush, the former President of U.S, and in 2002 the President of the U.S and the son of the former President, George W. Bush (Jnr.), launched another attack on the Iraqi government under the disguise that the Iraqi government, under the leadership of president Saddam Hussein, was in possession of nuclear weapon of mass destruction. Whereas the underlying intentions of the U.S government were hinged on the following: for George W.Bush Jr, to finish the uncompleted mission of his father during the Persian Gulf War; to avenge the terrorist attack on the U.S on September 11, 2001, which claimed the lives of over 3000 people more than 16,000 people being injured at the 110 storey building of World Trade Centre, in New York City. This was the result of the action of a team of 19 hijackers on a suicide mission believed to have been sponsored by Osama Bin Laden with the support of Saddam Hussein. It became imperative for America (U.S) to send a terror signal to the nations considered as axis of evil, by George W. Bush, to desist from acts that are capable of undermining the integrity, pride and superiority of the U.S government.

If U.S policy formulation and implementation on international diplomacy and economy triggers the act that could be described as terrorism in the world view, Saddam Hussein's roles in the Middle East, especially in the development of oil as an economic weapon against the West; his use of chemical weapons against Iranian forces in 1988, the annexing of Kuwait in 1990 and the numerous deaths associated with his regime give credence to the fact that he was a terror to his people and the rest of the Middle East before he was captured by the U.S led coalition forces in December 2003, in Tikrit.

However, the reign of terror in postcolonial Africa can be traced to both history and mythology. Modern African states often see democracy as an imposed system of governance that must be avoided. This idea of modern democracy, as being projected by the Western nations, is seen as a neocolonial syndrome that must be fought against and won by the African leaders. But the leaders themselves are ambitious and they would rather sit-tight and perpetuate themselves in power for life. Idi Amin, for example, in Uganda led a military coup against Milton Obote in 1971, and in 1976 he appointed himself as the life President of Uganda, killing over 300,000 persons considered to be intellectuals or political opponents until he was overthrown in 1979 by the Tanzanian army with help from Ugandan rebels operating outside Tanzania (Kasfir, 2006). The leadership process in Africa, from the historical perspective is associated with the following: a leader is chosen to lead as a mark of honour and trust, as in the case of a warrior that delivered his people from the jaws of slavery, and a leader is chosen as a mark of continuity of the royality and its divine aura as in the case of the Yoruba ethnic nationality of Western Nigeria (Amadiume, 2001). However, the Nigerian political terrain has witnessed quite a number of self-imposed leaders, like Yakubu Gowon, Mohammadu Buhari, Ibrahim Babangida, Sanni Abacha and Olusegun Obasanjo who may be seen as the most ambitious leaders in Nigerian politics. As Heads of their various governments in Nigerian history, they never evolved policies that truly promote democracy and transition to civil rule, but they were concerned about how to perpetuate themselves in power.

Inordinate ambition is synonymous with the leadership problem in Africa even though some Asian, Latin American and European countries are not left out of this. The North Korean effort at producing Nuclear Weapons is targeted at making herself more powerful than her neighbors who are considered as the allies of the U.S. The most striking thing about an inordinate ambition is the attendant terrorism and torture which the leaders always exhibit. The politics and paradox of power have exhibited all manners of terrorism as a result of the inordinate ambition of the various leaders of the world.

\section{Terrorism and inordinate ambition in Many Colours make the Thunder-King}

Osofisan's Many Colours Make the Thunder-King is a 
typical example of plays that explore the dynamics of power in the political arena, and it also highlights the psychological strength of terrorism as a means of power acquisition for an ambitious one. It is a play that has subverted the history and myth of one of the most dreaded gods/ Kings in the Yoruba pantheons, and the story events in the play have been crafted in a manner that gives them social and political relevance in a postcolonial state. Beyond the Yoruba world view on the myth of Sango, the world view of this mythology can easily be understood in this play. The attempt by Osofisan in the play is not be faithful to both the historical and the mythological landscape of Sango but an attempt at examining the nature of political power, and then draw a conclusion that the gods were men and that they were also susceptible to emotional weakness. The gods also cry; they are not infallible in the quest for inordinate ambition.

In the play, Sango is a successful warrior and a king, and he has conquered more towns and villages than his father, Oronmiyan, but with all these, he is less satisfied. His major concern is to do what has never been done before by his fathers and ancestors, and this is, by marrying Oya, the Princess of the river, Osun the Princess of the Forest and Oba the Princess of the Mountain. Though he succeeds in marrying Oya and Osun through the help of his servant, Alagemo, but his effort at going to marry Oba the princess of the mountain is subverted through a plot hatched by his generalsGbonka and Timi- with the support of Oya and Osun, as a result of jealousy and rivalry. Osun is well blessed with a lot of children but Oya is barren, but when Osun decides to help Oya, she is then taken to Yeyelroko whom Oya makes a vow that if she is given a child, by Yeyelroko, the child shall be given to Yeye Iroko as a sacrifice. But the attempt by Oya, to want to be the only wife of Shango makes her conspire against Osun and Alagemo, by alleging that they are both lovers. This results in Sango banishing Osun, and then places death sentence on Alagemo by being walled up in a vault. Shango is later deceived by Oya that his generalsGbonka and Timi- are plotting against him and this makes Sango to order a fight between them. This fight leads to Timi being beheaded by Gbonka. Having been victorious in the fight Gbonka challenges Sango to a fight which results in Shango losing his throne to Gbonka. Sango's inordinate ambition to become greater than his father, Oronmiyan, leads to the loss of his kingdom, his wives, Oya and Osun, children, his friend and spiritual mentor, Alagemo and his faithful and powerful generalsGbonka and Timi.

Osun, my wife! Ah what cruel jokes the gods play on us! All I wanted was to be greater than my father! But see! I've lost my precious wife, and my dearest friend! I've lost my throne.

And the town behind us, reduced to cinders by lightning! It is not enough then to marry a river, and wed a forest! One must still conquer a mountain, the mountain within yourself! ... Let me go, let the earth renew itself! I must stop here, and return home to join the ancestor (Recent Outings..., 1999: 236-237).

Sango as a metaphor for every man's innate inordinate ambition forms the basis upon which Osofisan's Many Colours..., may be studied. Unlike in the previous dramatic uses of the historical and mythical transformation and deification of Sango in Duro Ladipo's Oba Ko So (1978) with the attendant ritual and traditional colouration, the treatment of Sango's myth by Osofisan is not an attempt at promoting the cultural values and religious aesthetics alone but a deliberate subversion of a story and mythology that have been guided jealously by the Yoruba faithfuls of Sango. To Osofisan, Sango is a symbol of the individual mind; a probe into the dialectical state of humanity in a complex and dynamic universe of postcolonialism.

However, it must be stated that the play does not intend to celebrate the weakness, tragic flaws and end of Sango as an individual, but an appraisal of an irredeemable destruction that an individual's action could bring on himself and his society. Alagemo's monologue proves this:

Go, my king, but neither you nor your queens will be forgotten. Sango Olukoso mi! Yours has not been the useless death of pot-shards! No! You go in lightning and in rain, and your death renews the earth! Salute, my fiery king. Your queens return to fertilizing origins in the bosom of mother earth. Osun joins forces with Oya, and both your wives will act as our intercessors with Olokun of the sea! The cycle is complete; the cycle goes on.

Sango o! Whenever lightning strikes now in the world, and thunder rumbles, men will recall your legend, and shout your name! Oba koso o! You who gave birth to a terrible thunder storm, and burnt a whole city, whose wives became the source of rivers! Salute (Recent Outings.., 1999:238).

The Sango of the Yoruba pantheon was a great warrior and a king that was loved by his people, that even in death, his people still worship him as a god and also remember him as a king (Obafemi, 2001:18-20). But the most interesting aspect of his life which could serve as a moral lesson for humanity in the moment of crisis, and political and social transition and rejuvenation, is the concern of Osofisan in Many Colours...Every individual is imbued with innate dreams, and in an attempt to achieve these dreams, many run contrary to the dictate of the society and the reality of things. This does not mean that dreams or desires are not fundamental to the growth and development of the society or individual but a thirst for a tall dream begets a tragic end. Mans' aspiration in life, especially in Yoruba culture, or in the world view, is for a child to be greater than his father, in terms of achievement. 
SANGO: IGUNNUN:

Dancer, men became mountains.

SANGO: $\quad$ Our people say - a man begets a child, and later, the child becomes a father.

IGUNNUN: But they also add, my fiery king: "The

child, however tall, does not become

a man until he has grown to become

the father of his father"(Recent Outings..., 1999:151).

A strong pursuit of extraordinary achievement becomes, sometimes, the dream of some people to live a happy life but Osofisan sees it differently as "We are human beings; we do not need extraordinary feats to live a happy life" (Recent Outings..., 1999:153). The U.S. government, under President George W. Bush Jnr. is a good example in this regard. General SanniAbacha, former maximum Military Head of State in Nigeria, in an attempt to be greater than his predecessor, General Ibrahim BadamosiBabangida, ended up traumatizing the Nigerian society with wanton killings, corruption, phantom coups, inflation, self-succession bid, etc. His aspirations and dreams led to his sudden death in 1998. Perhaps, the basic inspiration behind the dramaturgic composition of Many Colours... was significantly triggered by the military administration of General SanniAbacha, and Osofisan had a prophecy on the end of the brutal reign of Abacha by using the metaphor in the myth of Sango. Osofisan wrote Many Colours... in 1997, the year that was regarded as the peak of Abacha's reign with attendant crimes against humanity.

The social responsibility of a playwright in the society is structured in a manner that his creative effort speaks to the immediate and future needs of the society. He draws inspiration from history (the past), myth, legend and folktales of the people. Osofisan's vision, in Many Colours... is multifacetedin terms of aesthetic appeal. The aesthetics of his themes can best be appreciated within the confines of the international politics and diplomacy, and they should not be viewed as a graphic illustration of the negative impact of war and aggression alone. Although, to Tzu (2002), war is imperative for peace to reign; that after war there must be peace, through reconciliation, rehabilitation and reconstruction. If Sango had not been made to purge himself of his thirst for tall ambition which leads to his tragic and heroic end, perhaps, he may not have had the status of a deity he assumed in the play after his death. Osofisan also makes Sango to reconcile himself to the emotional ambiance of humanity by way of submitting himself to the effect of his action, as a way of atoning for his misdeeds, having realized his fooleries.

No! I know how much smaller than my father I am! He could never do this, to banish his wife unjustly, condemn a faithful servant, and then accuse, without proof, his own generals. Ah! How much more I need to learn? (Recent Outings..., 1999:229)

To Osofisan, it is essential for a leader to learn to humble himself, and also own up to his mistakes, as a mark of greatness and that;

Compassion is the only weapon you need to be greater than your father. Wisdom, humility, these are the ways to greatness, to the truly memorable feats of legends (Recent Outings..., 1999:231)

This is one side of the virtue of Sango, as a compassionate tragic hero, which DuroLadipo omitted from his Oba Koso (1978), and Osofisan sees Sango as a true leader for this heroic deed of being compassionate in addition to Osun's benevolence and opulence to humanity. For example, despite the selfish act of Oya, which contributes largely to the fall of Sango, Sango is still a good and considerate husband with a large heart, full of compassion:

My friend, if I take the kingdom back, I can never rule it again with the same confidence, or the same innocence! I have been corrupted by unwilling acts of injustice. And the memory of my disgrace by my generals stands between me and my authority. I longed for power, I wanted to be greater than my father, but see how far I have fallen! ... So if I have to choose, I opt for Oya'sson (Recent Outings..., 1999:230)!

Being compassionate is also in the ability to be rational, especially during emotional crises, and also to judge one's action in order to determine how one has been able to project the principle of social justice, rule of law and fair play. Shango does not want to deceive himself, he realizes that the human nature or impulse in him may find its way into his judgment if he takes back his kingdom, but as a sacrifice through compassion, he chooses to ask for Oya's son to be given back to her.

Poor woman, she has lived this past year for nothing else!

... this son is the only seed that has agreed to take root in Oya's womb. And how she has suffered for it! l've always

loved her. Therefore, Alagemo, if there's still a power you can use for me, I have only one wish today - bring Oya's child

back to her arms (Recent Outings..., 1999:230-231).

However, in contrast to Shango's characteristic aggression and war mongering, Osofisan sees a symbol of a dynamic universe in Alagemo. As chameleon, Alagemo is susceptible to changes; he possesses power to change his form, to reflect the variety of life unlike Shango that is limited to being king and a warrior.

The metaphor here must be appreciated against the backdrop of the human mind or heart which ultimately determines his aspirations and ambitions. In addition to this, colours tell different stories about emotion (mood) 
and life, and Alagemo is a symbol of colours that give expressions to man's actions. Alagemo is a symbol of universal variety; a reflection of the flexibility and radical transformation of humanity, showing dual purpose of ideology. A positive change in the social order and a true democracy can only be attained when a man searches inward, the innermost part of his conscience. Shango sees all the vanities of life as the basis for greatness while Alagemo opts for a true conscience, and this leads to every transformation he achieves in the play. Alagemo's power and conscience is not for deception and arrogance; not for war and bitterness but for goodwill and progress of humanity in a postcolonial state.

This gift I have, it's not for trifling with..Imagine such a power in the hands of evil people. Rascals interested only in their own ambitions! Politicians, scheming for power. Generals with their eyes on the throne! A rogue with his eyes on someone else's wife! Can you imagine the chaos that will fall on the world? (Recent Outings..., 1999:198199).

\section{Metaphorical aesthetics/philosophy}

A good assessment of Many Colours... within the limits of aesthetic philosophy of Osofisan would provide a variety of dimension for which the play could be analyzed. Such analysis could also be seen from the perspectives of 'individual against the state', 'the dynamics of man in the webs of ambition' and the role a man in the corporate existence of the diverse ethnic nationalities in a state. Shango's ambitions and insatiable thirst for power and prowess could be regarded as a direct confrontation against the state ethos and peace just as his inability to manage his home, is pointer to the fact that he is not a leader that is capable of leading a state with diverse ethnic nationalities and opinions.

However, the metaphorical aesthetics in the play may be viewed from a wide range of thoughts - ideological interests which have immediate and future relevance to the contemporary world especially as a postcolonial state. For instance, the transmutational nature of Igunnu and Alagemo is a symbolic representation of a man and a state in transition. Igunnu and Alagemo could be viewed as a state in the hand of a leader in a state subjected to different abuses and uses for selfish reasons. The metaphor of Igunnu could be viewed thus: he possesses different colours which could be seen as an endless wealth; he has the tendency to reduce and increase his height, a symbolic feat that enables him to see into the past and future; a variety of colours and the ability to reduce and increase his height could be viewed as the dynamics of human nature, especially in terms of behaviours and development. It also symbolizes the composite of life (existence) and the society in terms of the sociopolitical, religious and economic policies which are sometimes inconsistent with the ambition of man. To Osofisan, many colours do not make a man to be strong or to live longer, but it is just a show of beauty that could easily fade away. The paradoxical nature of Alagemo could also be viewed as a way of adapting to situation one finds himself at a particular point in time. Like a postcolonial state, Alagemo adapts to the colours, texture, and the symbolic comfort, peace, inherent in the environment thereby projecting the philosophy of crisis management and resolution through humility.

It is also paradoxical in this context that Igunnu and Alagemo are used, by Osofisan, to project the human nature in a state. To Osofisan, however, man should adopt the wisdom and humility of Igunnu and Alagemo just for the progress and growth of the society. A postcolonial state needs the characteristics of Igunnu and Alagemo in a leader unlike the ambitious and aggressive nature of Shango. However, Igunnu is a masquerade that is common among the Yoruba ethnic subgroup in Nigeria. It possesses the ability to increase and decrease its height. The masquerade of Igunnu is made from different colours while Alagemo is the chameleon. Chameleon is a small reptile that changes its colours, depending on the environment it finds itself, just for the purpose of disguise, peace and comfort. This nature could be seen as a sign of humility and security. Alagemo goes about with ease, yet it is very wise. A transformation of Igunnu to Alagemo is to further heighten Osofisan's ideological view points on the dynamics of man as a leader in a society in transition.

The phenomenon of River, Forest and Mountain as wives of Shango is a subtle description of Nigeria as a state with a diverse ethnic nationalities whose wealth, through mineral and natural resources, are being tapped for the corrupt enrichment of the leaders. Shango may be viewed as a corrupt and ambitious leader whose interest in ruling the state lies in the amount of wealth he acquires, and the wives, Oya, Osun and the Mountain which he never married - represent the three major ethnic nationalities in Nigeria and the kind of love, hatred, treachery, suspicion, that exist among them are explored by Osofisan, to build the characters of Oya and Osun.

Beyond the ethnic rivalry and hatred in Many Colours..., Osofisan's treatment of the acts of betrayal, treachery and senseless killing in the Yoruba history and myth of Sango, the Alaafin that ordered his generals to fight each other in order to prove a point, is a metaphor for the contemporary world. The fight between Timi and Gbonka is a way of exhibiting Shango's power as a leader whose ambition beclouds his sense of reasoning. Many Nigerian leaders find it easier to see their subordinates as capable of plotting evil against them and the only rational thing, for them, to do is to also plot to get them off even though they are the most loyal subordinates. In 1997, the General Sanni Abacha led government announced a fathom coup purportedly planned by his subordinates, Lieutenant General Oladipo Diya and other prominent 
Nigerians, and their consequent trials and sentence to life in prison and death. To Osofisan, the mythical and historical event in the beheading of Timi by Gbonka, through the order of Sango is a metaphor for leaders who cannot divorce the state interest from personal interest; that when leaders push the ruled too far the poor can be made stronger, and they will liberate themselves. The radical and revolutionary disposition of Gbonka is the concern of Osofisan in this mythology. It is an attempt at a search for harmony and social order though history, myth, legend and the sociopolitical reality in Nigeria. While Gbonka's anger and aggression may be considered justifiable and dispassionate, Shango's is propelled by his ambition, and the metaphoric philosophy which Osofisan explores here places the contemporary leaders on a prism that reflects their war mongering disposition against the backdrop of their political antics that are devoid of diplomacy. Like Shango, who would transform into any situation, the African leadership knowing fully well that the call for constitutional democracy is the order of the day, they would transform from military rule into civilian rule just to legitimatize their rule. Shango in Many Colours..., is a metaphor for President Ibrahim BadamosiBabangida who transformed from Head of State into a civilian president, through a manipulated electoral process as it is done in other African countries where dictatorship and totalitarianism prevail. To Osofisan, however, a military leader cannot appreciate democracy because he is a warrior; his warlike nature will becloud his diplomacy.

Another aspect that is essential to the metaphorical aesthetic philosophy of Osofisan in Many Colours... is in his use of Esu. Like in his other plays, Esu and the Vagabond Minstrels (1988), Another Raft (1988) and Once Upon Four Robbers (1982), Esu is the Lord of the cross roads and justice; the errand god to other gods in the Yoruba pantheon, especially Orunmila. His duty is to put to test, the conscience of man in order to prepare him for the responsibility which the gods want him to carry out for the good of the society. Shango, a warrior, king and achiever of wonderful feats is not speared from this Esu's test. Esu, to Osofisan, is a check on man and his ambition, and the society. Esu, though a trickster, but he is compassionate and administers justice accordingly. It is a metaphor for the world that no one is above justice and equity as represented by Esu.

The metaphor of violence and freedom plays itself out in Many Colours..., as concepts in modern sociopolitical arena. Marxist aesthetic symbolizes that freedom could only come through a radical and revolutionary means, and this may be chaotic in nature. To Osofisan, freedom does not come, only, through negotiation except through violent means; when Alagemo is freed by Shango from the fruit of Odan tree just for the purpose of serving him, Osofisan aims to guide against what Alagemo says:

Because you freed me by the way of violence, both of us will Part by the way of violence! (Recent Outings..., 1999: 157)

It is important for Osofisan to say the above so that the world would take caution against the use of violence to achieve selfish ambitions.

Shango as a modern politician needed to win the hearts of his women as his electorate and he had to employ tricks and deceptions for his purpose. Osofisan portrays Shango here as an individual that is deceitful, like a modern politician who would want the votes of electorate by all means even if it means killing and stealing. And beyond this women; the electorate should be wary of politicians, like Shango in Many Colours... Women are, however, painted like electorate that are easily deceived. Oya and Osun are symbolic electorate who are with different characters that reflect arrogance, pride and materialist whenever their votes are being canvassed for by the politicians without considering their true conscience and the service to humanity through sincerity. Osofisan does not want the electorate to be easily deceived into taking actions that will have negative impact on their future as Oya and Osun did in Many Colours...

\section{Metaphor of the third term agenda}

The most significant aspect of the story events in Shango's political exploits as delineated in Many Colours... is his ambition and on the third term agenda. Osofisan makes a political metaphor out of Shango just to speak to heart of the African leaders who would rather perpetuate themselves in power for life by transforming into different shades of colours and shapes. In Nigeria, for instance, the third term agenda of former President OlusegunObasanjo was stopped in 2006 when the then National Assembly refused to amend the aspect of the Nigerian constitution that allows only a second term. It is essential to note that Osofisan had predicted this metaphor of third term ambition in Many Colours..., before 2006, and Obasanjo's ambition only emphasizes Shango's attributes. However, like Shango, when Obasanjo's third term ambition did not scale through, he became a sole enemy of the people, especially the democrats who had opposed him. He used the state apparatus to intimidate those he perceived as his opponents. The Independent Corrupt Practices Commission (ICPC) and the famous Economic and Financial Crime Commission (EFCC) were used to discredit Obasanjo's opponents. The fear of the ICPC and the EFCC became the beginning of wisdom for politicians. Like the proverbial 'many colours of Igunnu and chameleon' the Nigerian constitution has been subjected to different colours right from 1914 when the Nigerian state was created through the amalgamation of the southern and northern protectorates by Lord Lugard, 
just for the purpose of satisfying the interest and the inordinate ambition of the politicians and people in government. It may not be too hard to say that many colours make the Nigerian constitution. In this wise, Oya is the first term, Osun, the second term and while Mountain makes the third term that never came through for Shango. Osofisan only wants the politicians and the people to learn from Shango's story.

\section{Shango and Alagemoas visionary artistes}

In Many Colours..., Shango and Alagemo are portrayed as dancers, singers, drummers, poets or wordsmith and painters, with vision and commitment. This is indeed a metaphor for the contemporary artistes, especially the dramatist whose creative efforts and ingenuity should be used for a purpose that will transform the society positively. Arts have a great influence on the people rather than force. Shango as a warrior could not have achieved all his ambitions until he sought the assistance of Alagemo, a dancer, singer and painter. Shango needed the politics of arts to achieve his aims rather than deploying his aggression, and the warfare, and it was when he failed to employ the arts that his ambition fell. However, creative arts in this perspective may be considered as the intellectual reasoning of the leaders. A leader should be critical of his action especially its implication on the life of the people and the society.

\section{Environmental pollution and the ants}

Perhaps, one of the high points in Many Colours..., in terms of socioeconomic reality, is the scene involving the Ants and Alagemo. Alagemo, having been walled up in a cave to die, by Shango, the Ants appeared and Alagemo was helped to escape through a tunnel dogged by them. Osofisan wants us to see and value the relevance of Ants in the bio-degradation of human pollution of the earth. Ants are humanitarian, and they possess economic and social value that could be used by the people. The scene also symbolizes that 'no matter how powerful and wise one is one should not underestimate any individual in the society'. Every individual should be valued just as earth should be protected from all forms of pollution. The earth that yields foods and life to humanity should be protected, and ants find themselves performing these responsibilities instead of involving themselves in the politics of human beings.

That is why we've not been paying much attention to the politics of human beings. It is usually the same thinganyway, year in year out. Violence, fraud, deception, only the occasional kindness. Someone killing another to grab a throne or steal a spouse. And the poor peopleexchanging one chain for another, travelling down anendless route of mistery, from one slave-master to another (Recent Outings...,1999:208).
The metaphor in the life of ants, as most orderly and organised animals, is used by Osofisan as a way of making human beings to learn the art of diligence, love, devotion, hard work and commitment. Ants are very organized and faithful to their works and vows. To human beings therefore, people should imbibe these virtues for the progress and growth of humanity. The riddles of the ants should also be considered as the endurance test that every human being must go through before he can achieve his goals. For Alagemo to solve the riddle involving mountain, road, tree, dew drops, the drum, salt, and tomorrow, before he could be helped by the ants is as putting human beings to such rigorous test just for them to appreciate and value whatever good thing that comes their way at a moment of crises, and also that human efforts, through national and conscious means, could trigger development and growth. It is also important to note that ants' life style could provide a good example of the kind of life that human beings could live. Ants live an orderly and organized life. In fact, orderliness is central to the existence. They are always on the cues to take their turn. Osofisan's intention in this regard is to show the power and politics behind the successful living in the ants' kingdom where love, unity, harmony and friendship play vital role in the development and growth of every ant.

In Osofisan's plays discussed above, it has been established that metaphor is a central idiom in the artistic and ideological projection in his drama and theatre. These plays could be viewed within the multiplicity of issues prevalent in a postcolonial state seeking growth and development, sociopolitical identity through of her history, mythology, legend and the means of education and entertainment, like folklore. The metaphorical imports of these plays should appeal to the varying ideological and aesthetic criticisms of the drama and theatre emerging from a postcolonial state as a mark of a comparative study for a better society. The universal appeal and thrust in these plays can only be brought to the fore if the metaphorical contents and contexts in them are explored against the backdrop of the Nigerian sociopolitical, religious and historical realities for metaphor is a pervasive medium. It must be noted, however, that metaphor manifests as an enduring mode for radical social vision, and as a vehicle of revolutionary action in Osofisan's drama. His radical metaphorisation and interpretation of myth, history and folklore is for the purpose of theatrical presentation of postcolonial issues of corruption, inordinate ambition, dictatorship, political terrorism and abuse of power, environmental pollution, poverty, ethno-religious intolerance, injustice, democratic and election/selection matters, amongst others.

\section{REFERENCES}

Amadiume I (2002). Deconstructing African History. Fanon F (1963). The Wretched of the Earth. England: Penguin Books. Kasfir N (2006). "Idi Amin" in Microsoft ${ }^{\circledR}$ Student 2007 (DVD. 
Redmond, WA: Microsoft Corporation.

Ladipo D (1978). Oba Koso. Ibadan: University Press.

Osofisan F (1974). "The Origins of Drama in West Africa: A Study of the Development of Drama from the Traditional Forms to the Modern Theatre in English and French" Unpublished Ph.D Thesis submitted to the Department of Modern Languages, University of Ibadan, Ibadan.

Osofisan F (1978).The Chattering and the Song. Ibadan: University Press.

Osofisan F (1997).Playing Dangerously Drama at the Frontiers of Terror in a "Postcolonial" state. Ibadan: University of Ibadan.

Osofisan F (1998). "Reflections on Theatre Practice in Contemporary Nigeria" in African Affairs. Oxford: University Press, Vol. 97, No. 386. 81-89.

Osofisan F (1999). "Theatre and the Rites of "Post-Negritude" Remembering".Res. Afr. Lit.30(1):1-11. Indiana: University Press.

Osofisan F (1999)."Tegonni": An African "Antigone" and "Many Colours Make the Thunder-king" in Recent Outings. Ibadan: Oponlfa Readers.Is this referencesfor all the (Recent Outings?)

Osofisan F (2001). Literature and the Pressures of Freedom: Essays, Speeches and Songs. Ibadan: Oponlfa Readers.

Osofisan F(1972). Theatre and Nationalism: Wole Soyinka and LeRoi Jones. Ile-Ife: University Press Ltd.

Osofisan F(1975)A Restless Run of Locusts.lbadan: Onibonoje Publishers.

Osofisan $\mathrm{F}(1986)$.Farewell to a Cannibal Rage. Ibadan: Evans Publishers
Osofisan F(1988). Another Raft. Lagos: Malthouse Press.

Osofisan F(1990). Fires Burn and Die Hard. Lagos: Malthouse Press Ltd.

Osofisan F(1990).Birthdays Are Not for Dying. Lagos: Malthouse Ltd.

Osofisan F(1991). Command Performance of Farewell to a Cannibal Rage, for the visit of President Ibrahim Babangida to Oyo State, Ibadan: Dept of Theatre Arts.

Osofisan F(1993).YungbaYungba and the Dance Contest. Ibadan: Heinemann.

Osofisan F(1999). Morountodun and Other Plays. Lagos: Longmann.

Osofisan F(2001). Insidious Treasons: Drama in a Postcolonial State (Essays). Ibadan: Oponlfa Readers.

Osundare N(1980). "Social Change of a Nigerian Dramatist" in West Africa. 3262 (28 January):147-150.

Pavis P(1993). "Production and Reception in the Theatre", in New Directions in Theatre. Julian Hilton (ed.) London: Macmillan, 23-31.

Tzu S (2002). The Art of War. Published: February 24, 2002. 